\title{
Effect of Different Rennet Type on Physico-Chemical Properties and Bitterness in White Cheese
}

\author{
Tulay Ozcan and Ufuk Eren-Vapur
}

\begin{abstract}
White cheese is a soft or semi-hard cheese variety of the brined cheeses family which had its origin in the Turkey and other Mediterranean countries. The changes in physicochemical properties, proteolysis and bitterness of White cheeses made from animal-calf rennet (A) and microbial rennet from Rhizomucor miehei $(M)$ were investigated during a 90 day ripening period. Physico-chemical characteristics were similar for cheeses made with both types of rennet. Phe, Leu - Ile, Gln, Val, Pro and Ala were the principal free amino acids (FAAs) in the White cheeses at all stages of ripening. The differences in the contents of the total bitter tasting amino acids (Phe, Leu - Ile, Val and Pro) were not influenced by the type of rennet.
\end{abstract}

Index Terms-White cheese, rennet, free amino acids, bitterness.

\section{INTRODUCTION}

Cheese is one of the most widely consumed fermented dairy products with a growing consumer demand. It is an excellent dietary source of high-quality protein, vitamins and minerals such as absorbable dietary calcium. Hundreds of types of cheese are produced in the world. Their styles, textures and flavors depend on the origin of milk, animal's diet, butterfat content, bacteria and mold, the processing, and aging conditions [1], [2].

Turkey is one of the largest producers of dairy products. There are more than 100 varieties of cheese in the country; however, because of manufacturing similarities, it is possible to group them into fifty different types [3]. Turkish White cheese is the most popular cheese variety in Turkey, representing approximately $60 \%$ of the country's total cheese production. This is originally manufactured from sheep or goat's milk, but cow's milk or a combination of milks is now generally used for its production. White cheese is a soft or semi-hard texture, brine-salted, with mildly rancid and slightly acid taste, firm and smooth texture ripened in brine $(12-14 \mathrm{~g} / 100 \mathrm{~g} \mathrm{NaCl}$ solution) for the period of 1-3 months [4]- [6].

Cheese is produced by coagulation of the milk protein casein. The essential ingredients in cheese making are milk and a protein coagulant such as rennet and/or acid. Rennet is an enzyme mixture of chymosin types $A, B$ and $C$ as well as

Manuscript received January 2, 2013; revised February 15, 2013. This work was supported in Commission of Scientific Research Projects of Uludag University, Bursa, Turkey under Grant (Z)-2008/19.

Tulay Ozcan is with the Department of Food Engineering, Faculty of Agriculture, Uludag University, Bursa, Turkey (e-mail: tulayozcan@uludag.edu.tr)

Ufuk Eren-Vapur is with the Technical Adviser. Mayasan Food Industries A.S. Istanbul, Turkey. pepsin from stomach of claves and other ruminant mammals. The most highly active enzyme in animal rennet is chymosin. It causes the coagulation of milk by cleaving the $\mathrm{Phe}_{105}-\mathrm{Met}_{106}$ bond of $k$-casein [7], [8].

The coagulation of the milk is traditionally made by calf rennet in White cheese manufacturing [6]. Animal rennet is traditionally manufactured by extracting the abomasum, the fourth stomach of young ruminants, mainly of calves. However, the increased consumption of cheese has led to an increase in demand for rennet. Lately, enzymes from plants and animals, like lipase, chymotrypsin and trypsin from pancreas, rennin from calf abomasus and papain, a cysteine protease obtained from the papaya (Carica papaya, Carica Candamarcensis) are developed. Recently, enzymes for milk fermentation are also developed by genetic engineering, which provides a broad novel spectrum of innovative product conceptions. Instead of the traditional animal source, calf rennet-chymosin can be expressed by genetically modified microorganisms, like yeasts or fungi [9]- [12].

In recent years, microbial proteases are extensively applied in cheese manufacturing. Therefore, other suitable coagulants (bovine, porcine and chicken), including proteinases from microorganisms (Mucor miehei, Mucor pusillus, Penicillium roqueforti, Penicillium camemberti and Cryphonectria parasitica) have become more popular in the production of cheeses [11]-[14].

The objective of the present study is to investigate the effects of different rennet types (calf and microbial from Rhizomucor miehei) using different starter culture ratio on the physico-chemical characteristics and proteolysis of White cheese and research on production of bitter taste amino acids.

\section{MATERIALS AND METHODS}

\section{A. Materials}

Raw bovine milk supplied from Yorsan Dairy Company (Bursa, Turkey) was used in the manufacture of cheese samples. Rennet of animal (1/18 000: Mayasan Food Industries A.S. Istanbul, Turkey) and microbial (1/16 000: Mayasan Food Industries A.S. Istanbul, Turkey) origin was used to coagulate the milk. The starter cultures were obtained freeze-dried from Danisco (Brugge, Belgium). The mesophilic starter was a blend of Lc. lactis subsp. lactis and Lc. lactis subsp. cremoris, and the thermophilic starter was a blend of Lb. delbrueckii subsp. bulgaricus and Str. thermophilus in equal proportions.

\section{B. Methods}

White cheeses were produced by the traditional method of [4]. (Fig 1). The cheese-making trials were denoted as A, A5, A10, A20, M, M5, M10 and M20. White cheeses were 
made from either animal or microbial rennet using different ratios of starter culture, with three experiments, each repeated three times on different days. The experimental design of White cheeses is detailed in Table I.

TABLE I: EXPERIMENTAL DESIGN OF WHITE CHEESES

\begin{tabular}{|cccc|}
\hline Cheese Tpye & Starter Culture $^{\mathrm{a}}$ & Animal Rennet & Microbial Rennet \\
\hline $\mathbf{A}$ & ${ }^{\mathbf{b}}$ & + & - \\
\hline $\mathbf{A}_{5}$ & + & + & - \\
\hline $\mathbf{A}_{10}$ & + & + & - \\
\hline $\mathbf{A}_{20}$ & + & + & - \\
\hline $\mathbf{M}$ & - & - & + \\
\hline $\mathbf{M}_{5}$ & + & - & + \\
\hline $\mathbf{M}_{10}$ & + & - & + \\
\hline $\mathbf{M}_{20}$ & + & - & + \\
\hline
\end{tabular}

${ }^{a}$ Starter culture, Lc. lactis subsp. lactis and Lc. lactis subsp. Cremoris;

Lb. delbrueckii subsp. bulgaricus and Str. thermophilus, 5 DCU/tons, 10 DCU/tons and

20 DCU/tons (DCU: Danisco Culture Unit)

${ }^{\mathrm{b}}+$, addition; - , no addition

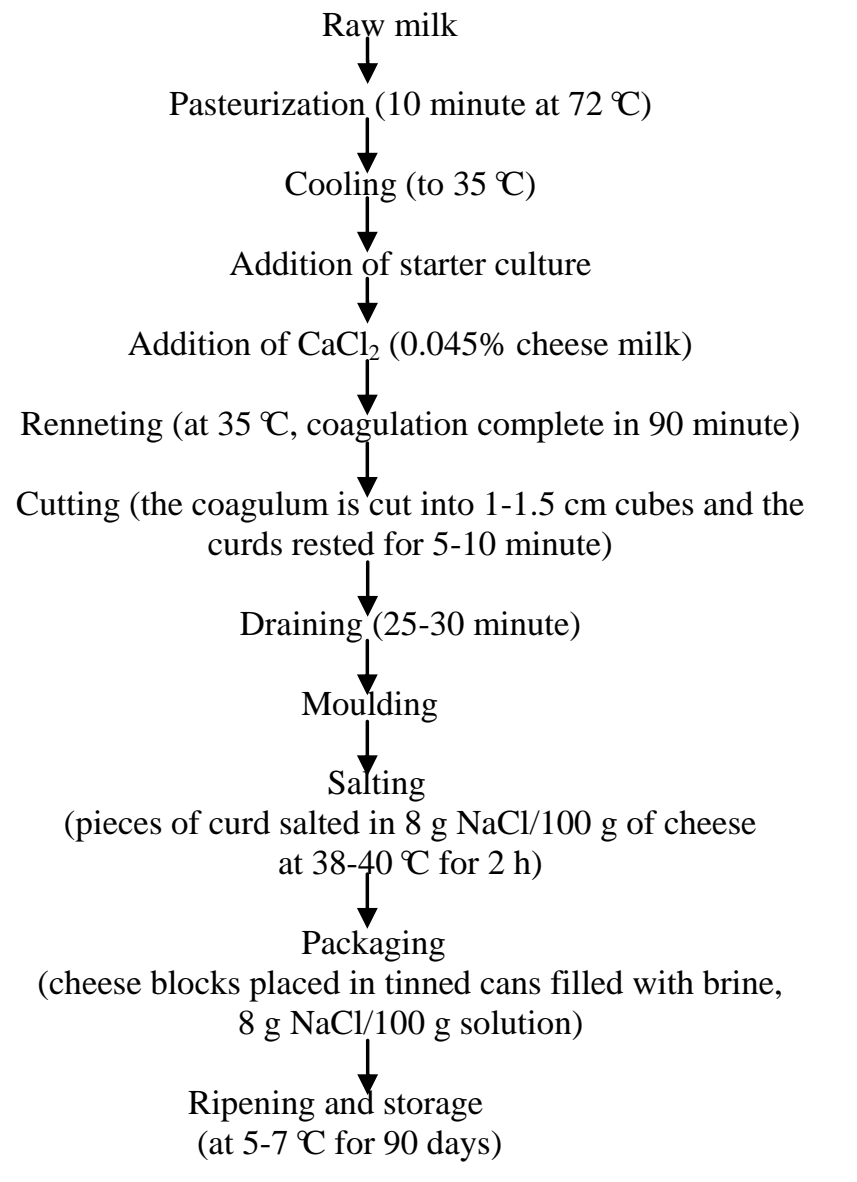

Fig. 1. White cheese production

\section{Cheese Analyses}

The following analyses were performed on the cheese samples: $\mathrm{pH}$ (internal and external) was determined with a potentiometer; titratable acidity ( $\mathrm{SH}$ : Soxhlet Henkel) was determined by titrating $10 \mathrm{~g}$ of sample with $0.25 \mathrm{~N} \mathrm{NaOH}$ to a pink endpoint using a phenolphthalein indicator. The dry matter (DM) of the White cheeses were determined by oven drying at $105 \pm 2{ }^{\circ} \mathrm{C}$, the fat composition by the Gerber method and the salt content of the cheese samples was determined by the Mohr method as described [15].

Formal titration (FT) was determined according to the Schilowitsch method modified by [16]. The N content, both the total nitrogen (TN) and nitrogenous fraction [water soluble nitrogen (WSN) and nitrogen soluble in $12 \%$ trichloroacetic acid (TCA-SN)], were determined by the Kjeldahl method [17]. A ripening index (RI) related to rennet activity was determined by the method of [18].

The free amino acid (FAA) content was employed in the determination of proteolysis using LC/MS according to the methods of [19]. Amino acid standards were obtained from Sigma Chemicals (Milwaukee, WI, USA), and all other chemicals used were of analytical grade (99\%). Quality assurance measures were employed for amino acids, which involved inclusion in each sample, duplicate samples spiked at $5,10,50 \mathrm{mg} / 100 \mathrm{~g}$ and a reagent blank. The amounts of FAAs in the various cheese samples were calculated using peak area values from duplicate analytical samples, and the peak areas were converted to concentrations using calibration curves of amino acid standards.

All chemical measurements were done in triplicate. Cheese samples were chemically analyzed for the 90 days of ripening.

\section{RESULTS AND DISCUSSION}

The physico-chemical properties of White cheese during ripening are given in Table II. White cheese ripening and proteolysis were influenced by starter cultures and rennets $(\mathrm{P}<0.05, \mathrm{P}<0.01)$. The rates of proteolysis in terms of total nitrogen $(\mathrm{TN})$, water-soluble nitrogen (WSN) and ripening index (RI) were affected by starter culture and ripening time. Physico-chemical characteristics were similar for cheeses made with both types of rennet. The milk clotting enzymes contribute to proteolysis in Turkish White cheese. This is due to the high coagulant retention of the cheese curd with high moisture content, and also due to storage of cheese in salted whey that contains residual coagulant. The use of calf rennet and microbial rennets (e.g., R. miehei) and their implication on proteolysis during cheese production have been demonstrated by [20]-[24].

The physico-chemical properties of White cheese are defined in the Turkish Standard TS 591. According to this standard, the cheese should have a $3 \%$ maximum titration acidity in terms of lactic acid, must have a $\mathrm{pH}$ value over 4.5, a maximum moisture content of $60 \%$ and a maximum salt content of $10 \%$. The milk fat amount should be at least $45 \%$ in whole-fat White cheese, $30 \%$ in regular fat White cheese, $20 \%$ in medium-fat White cheese and less than $20 \%$ for low-fat White cheese [25].

Proteolysis is usually regarded as the main biochemical process during cheese ripening and one of the most important factors for the development of typical cheese flavor and texture. Proteins are partially hydrolyzed by rennet and other native microbial enzymes (the starter bacteria, and the non-starter microbiota) to produce lowermolecular-weight compounds. They are further broken down by peptidases into various nitrogenous substances, such as proteose, peptone, amino acids and amines [26][27], [28]. 
TABLE II: THe CHANGES IN PHySIO-CHEMICAL PROPERTIES OF White CHEESES DURING RIPENING

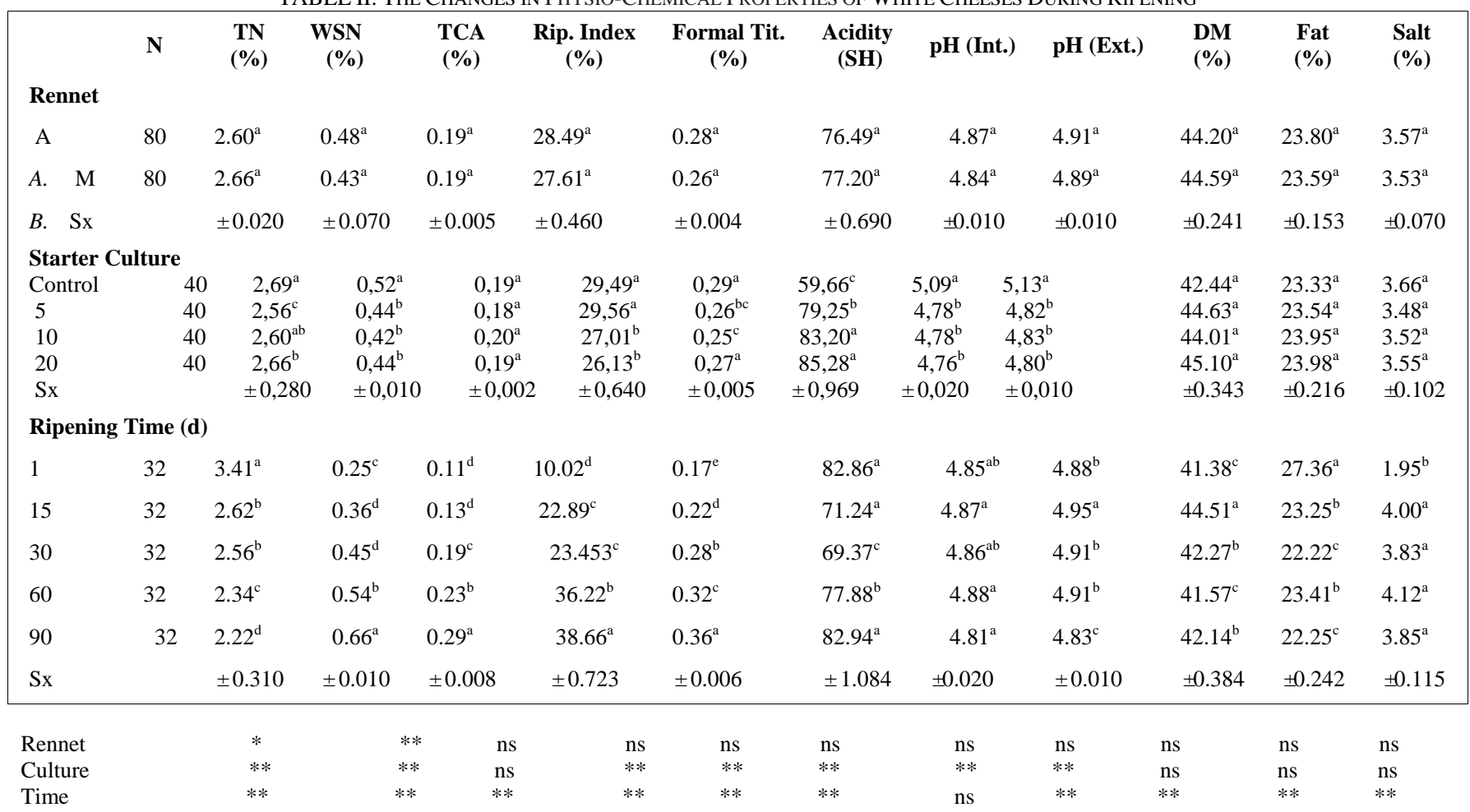

Significance level: significant at $\mathrm{p}<0.01(* *), \mathrm{p}<0.05(*)$, different superscript letters on the same column indicate significant differences, ns: not significant A: Animal rennet, A5: Animal rennet+5DCU starter culture, A10: Animal rennet+10DCU starter culture, A20: Animal rennet+20DCU starter culture, M: Microbial rennet, M5: Microbial rennet+5DCU starter culture, M10: Microbial rennet+10DCU starter culture, M20: Microbial rennet+20DCU starter culture

The average free amino acid (FAA) composition of White cheeses is presented in Fig 2. The total concentration of FAAs increased during ripening and Phenylalanine (Phe), Leucine- Isoleucine (Leu - Ile), Glutamine (Gln), Proline (Pro), Alanine (Ala) and Valine (Val) were the principal FAAs in the cheeses at all stages of ripening (Fig 2, Table III). Our findings are in agreement with our previous report that an amino acid content of white cheeses [24]-[29].

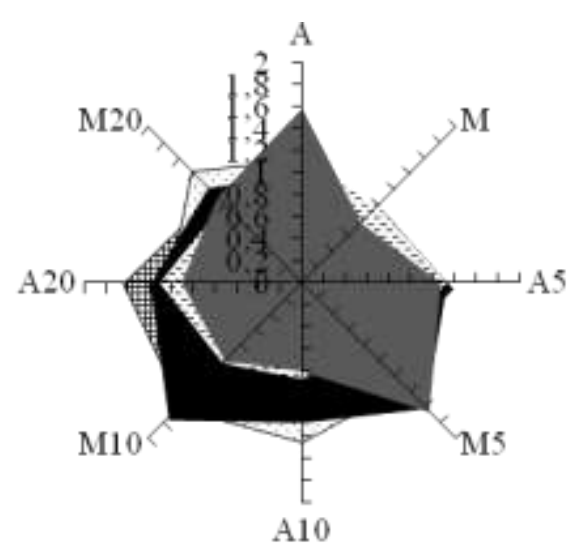

\section{口Day 1 Day 15 Day 30 Day 60 Day 90}

Fig. 2. Free amino acid content (mg/100 g of cheese dry matter) of White cheeses at different ripening periods

Proteolysis in Turkish White cheese continues during storage in brine. Starter peptidases are responsible for the production of amino acids. The addition of Lactic Acid Bacteria (LAB) as a starter culture produced higher content of short-chain peptides and FAAs during cheese ripening [30]-[31]. However, different starter bacteria release different levels of individual FAA [32] based on their enzyme system and the degree of autolysis in the cheese [33].

\begin{tabular}{|c|c|c|c|c|c|c|}
\hline \multirow{2}{*}{ Treatment } & \multicolumn{7}{|c|}{ FAAs sequence } \\
\cline { 2 - 7 } & $\mathbf{1}^{\text {st }}$ & $\mathbf{2}^{\text {nd }}$ & $\mathbf{3}^{\text {rd }}$ & $\mathbf{4}^{\text {th }}$ & $\mathbf{5}^{\text {th }}$ & $\mathbf{6}^{\text {th }}$ \\
\hline $\mathbf{A}$ & $\begin{array}{c}\text { Leu } \\
\text { Ile }\end{array}$ & Phe & Val & Pro & Ala & Glu \\
\hline $\mathbf{M}$ & Phe & Val & $\begin{array}{c}\text { Leu }- \\
\text { Ile }\end{array}$ & Pro & Ala & Asn \\
\hline $\mathbf{A 5}$ & Phe & $\begin{array}{c}\text { Leu - } \\
\text { Ile }\end{array}$ & Val & Pro & Gln & Asn \\
\hline $\mathbf{M 5}$ & Phe & $\begin{array}{c}\text { Leu - } \\
\text { Ile }\end{array}$ & Val & Pro & Ala & Gln \\
\hline $\mathbf{A 1 0}$ & Phe & $\begin{array}{c}\text { Leu - } \\
\text { Ile }\end{array}$ & Val & Pro & Ala & Glu \\
\hline M10 & Phe & $\begin{array}{c}\text { Leu - } \\
\text { Ile }\end{array}$ & Val & Pro & Gln & Ala \\
\hline $\mathbf{A 2 0}$ & Phe & $\begin{array}{c}\text { Leu - } \\
\text { Ile }\end{array}$ & Pro & Gln & Val & Ala \\
\hline M20 & Phe & $\begin{array}{c}\text { Leu - } \\
\text { Ile }\end{array}$ & Pro & Val & Ala & Hyp \\
\hline
\end{tabular}

Amino acid catabolism is a major process for flavour formation in cheese. The principal FAAs, including Leu, Glutamic acid (Glu), Phe, Val and Lysine (Lys), were present in the 60-day old Turkish White brined cheese made from pasteurized cow's milk [34]-[36]. Previous authors Alichanidis et al. [37], Katsiari et al. [38], Michaelidou et al. [39] have shown that Leu, Glu, Val and Lys were major FAAs in Feta cheese made from cow's milk. However, while the same FAAs were present in Iranian Brine cheeses after ripening for 50 days, this did not continue to the end of 
ripening in Feta; the amino acid Lys, Arginine (Arg) and Glu were predominant at the end of ripening in the cheese [40]. Table III shows the sequence of free amino acids values in White cheeses. The first two amino acids were Phe and Leu-Ile and they did not change based on the origin of the rennet (animal or microbial) and where as amino acids Val, Gln, Pro, Ala, Glu, Aspartic acid (Asn) and Hydroxyproline (Hyp) were found lower content.

TABLE IV: BitTer TASTe Amino ACID PROdUCtion IN Fresh White CHEESE

\begin{tabular}{|c|c|c|c|c|c|c|}
\hline \multirow{2}{*}{$\begin{array}{c}\text { Amino acid } \\
\text { (mg/100 g of } \\
\text { cheese dry matter) }\end{array}$} & \multicolumn{5}{|c|}{ Treatment } & \multirow{2}{*}{$\begin{array}{c}\text { Variation } \\
\text { in \% of total } \\
\text { amino acids }\end{array}$} \\
\hline & A & A5 & $\mathbf{A 1 0}$ & A20 & $\begin{array}{l}\text { Ave. } \\
\end{array}$ & \\
\hline Prolin & 3.030 & 2.465 & 2.490 & 1.840 & 2.456 & $11.31 \%$ \\
\hline Valin & 2.365 & 1.350 & 1.595 & 2.240 & 1.888 & $8.69 \%$ \\
\hline Phe & 4.235 & 3.260 & 2.895 & 5.680 & 4.018 & $18.51 \%$ \\
\hline Leu - Ile & 3.770 & 2.765 & 2.520 & 4.925 & 3.495 & $16.10 \%$ \\
\hline Total & 3.400 & 9.840 & 9.500 & 4.685 & & $54.61 \%$ \\
\hline \multirow{2}{*}{$\begin{array}{c}\text { Amino acid } \\
\text { (mg/100 g of } \\
\text { cheese dry matter) }\end{array}$} & \multicolumn{5}{|c|}{ Treatment } & \multirow{2}{*}{$\begin{array}{c}\text { Variation } \\
\text { in \% of total } \\
\text { amino acids } \\
\end{array}$} \\
\hline & $\mathbf{M}$ & M5 & M10 & M20 & Ave. & \\
\hline Prolin & 2.200 & 2.540 & 4.265 & 2.215 & 2.805 & $13.79 \%$ \\
\hline Valin & 1.745 & 1.470 & 2.350 & 1.545 & 1.778 & $8.74 \%$ \\
\hline Phe & 2.680 & 3.695 & 4.745 & 2.960 & 3.520 & $17.31 \%$ \\
\hline Leu - Ile & 2.105 & 3.110 & 4.110 & 2.625 & 2.988 & $14.69 \%$ \\
\hline Total & 8.730 & 0.815 & 5.470 & 9.345 & & $54.53 \%$ \\
\hline
\end{tabular}

A: Animal rennet. A5: Animal rennet+5DCU starter culture. A10: Animal rennet+10DCU starter culture. A20: Animal rennet+20DCU starter culture. M: Microbial rennet. M5: Microbial rennet+5DCU starter culture. M10: Microbial rennet+10DCU starter culture. M20: Microbial rennet+20DCU starter culture

TABLE V: BitTER TASTE AMino ACID PRODUCTION IN OLd White CHEESE FOR 90 DAYS OF RIPENING

\begin{tabular}{|c|c|c|c|c|c|c|}
\hline \multirow{2}{*}{$\begin{array}{c}\text { Amino acid } \\
\text { (mg/100 g of } \\
\text { cheese dry } \\
\text { matter) }\end{array}$} & \multicolumn{5}{|c|}{ Treatment } & \multirow{2}{*}{$\begin{array}{c}\text { Variation } \\
\text { in \% of total } \\
\text { amino acids }\end{array}$} \\
\hline & A & A5 & A10 & A20 & Ave. & \\
\hline Prolin & 2.350 & 2.250 & 1.310 & 2.070 & 1.995 & $9.50 \%$ \\
\hline Valin & 3.975 & 2.635 & 1.385 & 1.610 & 2.401 & $11.44 \%$ \\
\hline Phe & 6.850 & 6.155 & 3.525 & 4.650 & 5.295 & $25.23 \%$ \\
\hline Leu - Ile & 7.880 & 4.785 & 2.845 & 3.885 & 4.849 & $23.10 \%$ \\
\hline Total & 21.055 & 15.825 & 9.065 & 12.215 & & $69.27 \%$ \\
\hline \multirow{2}{*}{$\begin{array}{c}\text { Amino acid } \\
\text { (mg/100 } \mathrm{g} \text { of } \\
\text { cheese dry } \\
\text { matter) } \\
\end{array}$} & \multicolumn{5}{|c|}{ Treatment } & \multirow{2}{*}{$\begin{array}{l}\text { Variation } \\
\text { in \% of total } \\
\text { amino acids }\end{array}$} \\
\hline & $\mathbf{M}$ & M5 & M10 & M20 & Ave. & \\
\hline Prolin & 1.270 & 2.745 & 2.065 & 2.080 & 2.040 & $10.18 \%$ \\
\hline Valin & 2.205 & 4.075 & 2.375 & 2.005 & 2.665 & $13.30 \%$ \\
\hline Phe & 3.725 & 8.450 & 4.270 & 4.595 & 5.260 & $26.26 \%$ \\
\hline Leu - Ile & 1.975 & 6.700 & 3.330 & 3.105 & 3.778 & $18.86 \%$ \\
\hline Total & 9.175 & 21.97 & 12.04 & 11.785 & & $68.60 \%$ \\
\hline
\end{tabular}

A: Animal rennet. A5: Animal rennet+5DCU starter culture. A10: Animal rennet+10DCU starter culture. A20: Animal rennet+20DCU starter culture. M: Microbial rennet. M5: Microbial rennet+5DCU starter culture. M10: Microbial rennet+10DCU starter culture. M20: Microbial rennet+20DCU starter culture

Proteolysis results in an increase in peptides and free amino acids. Amino acids can influence taste of foods. Each amino acid has its own threshold value. During hydrolysis pepdides of varying sizes are formed but it is well known that some pepdides, especially those rich in hydrophobic amino acids taste bitter. Bitterness is influenced by the cheese making procedure and by factors such as strain of starter culture, rennet concentration, heat treatment of the milk, acidity or $\mathrm{pH}$ of cheese and salt concentration [41], [42].

Lemieux and Simard [41] and Urbach [43] observed that Val, Leu, Pro and Phe are major FAAs which forming bitterness. Kabelova et al. [44] reported that individual amino acids, seven amino acids were more concentrated in all cheese samples, and came from three distinctive taste groups: bitter tasting amino acids (Leu, Lys, and Phe), bitter sweet amino acids (Pro and $\mathrm{Val}$ ), and salty-umami amino acids (Glu and Asp). Table IV, V shows that total bitter taste amino acid production was not influenced by different rennets in fresh and old White cheese. However these amino acids were affected by starter culture ratio and bitterness increased during ripening period.

\section{IV.CONCLUSION}

Finally, as discussed above, the results are indicated that proteolytic action of $R$. miehei protease as microbial rennet almost the same effect with animal-calf rennet. The amino acids Phe, Leu - Ile, Gln, Val, Pro and Al were found most abundantly in the fractions of FAAs of ripened White cheeses. The ratio of basic bitter taste FAAs were not changed depend on rennet type.

Milk coagulation is the primary step in the development of texture and flavour of cheeses depend on specific enzymatic proteolytic degradation of milk compounds aspecielly proteins. In order to improve texturel properties and the nutritional value of cheeses and inaddition to decreasing in the number of young animals has lead the producers to the investigate alternative milk clothing enzymes of different origins. These include especially microbial enzymes are commonly accepted for lactovegetarians or for kosher products and are halal suitable.

\section{REFERENCES}

[1] P. F. Fox, T. P. O’Connor, P. L. H. McSweeney, T. P. Guinee, and N M. O'Brien, "Cheese: Physical, biochemical and nutritional aspects," Adv. Food Nutr. Res., vol. 39, pp. 163-328, 1996.

[2] G. H. Miller, J. K. Jarvis, and L. D. McBean, "Handbook of dairy foods and nutrition," 3rd ed. National Dairy Council, Boca Raton (FL): CRC Press, 2007.

[3] T. Ozcan, and E. Kurdal, "The effects of using a starter culture, lipase and protease enzymes on ripening of Mihalic Cheese," Int. J. Dairy. Technol., vol. 65, no. 4, pp. 585-593, 2012.

[4] A. A. Hayaloglu, M. Guven, and P. F. Fox, "Microbiological, biochemical and technological properties of Turkish White cheese: Beyaz Peynir," Int. Dairy J., vol. 12, no. 8, pp. 635-648, 2002.

[5] A. A. Hayaloglu, B. H. Ozer, and P.F. Fox, "Cheeses of Turkey: 2. Varieties ripened under brine," Dairy Sci. Technol., vol. 88, no. 2, pp. 225-244, 2008.

[6] U. Kamber, "The traditional cheeses of Turkey: cheeses common to all regions," Food Rev. Int., vol. 24, no. 1, pp. 1-38, 2008.

[7] P. F. Fox, T. P. Guinee, and T. M. Cogan, "Enzymatic coagulation of milk," in Fundamentals of Cheese Science. Gaithersburg, Maryland, USA: Aspen Publishers, Inc. 2000, pp. 98-135.

[8] D. S. Horne, and J. M. Banks, "Rennet-induced coagulation of milk" in Cheese Chemistry, Physics and Microbiology, P. F. Fox, P. L. H., Mc Sweeney, T. M. Cogan, T. P. Guinee, Eds, vol. 1, 3rd ed., Amsterdam: Elsevier Ltd., 2004, pp.47-70.

[9] J. R. Dutta, and R. Banerjee, "Isolation and characterization of a newly isolated Pseudomonas mutant for protease production," Braz. Arch. Biol. Technol., vol. 49, no. 1, pp. 37-47, 2006. 
[10] F. Hasan, A. A. Shah, and A. Hameed, "Industrial applications of microbial lipases," Enzym. Microb. Technol., vol. 39, no. 2, pp. 235$251,2006$.

[11] M. Jacob, D. Jaros, and H. Rohm, "Recent advances in milk clotting enzymes,” Int. J. Dairy Technol., vol. 64, no. 1, pp. 14-33, 2011.

[12] C. Beermann and J. Hartung, "Current enzymatic milk fermentation procedures," Eur. Food Res. Technol., vol. 235, pp. 1-12, 2012.

[13] C. J. Shieh, L. A. P. Thi, and I. L. Shih, "Milk-clotting enzymes produced by culture of Bacillus subtilis natto," Biochem. Eng. J., vol. 43 , no. 1 , pp. 85-91, 2009.

[14] K. S. Vishwanatha, A. G. A. Rao, and S. A. Singh. "Production and characterization of a milk-clotting enzyme from Aspergillus oryzae MTCC 5341," Appl. Microbiol. Biotechnol., vol. 85, no. 6, pp. 18491859, 2010.

[15] A. Kurt, S. Cakmakci, and A. Caglar, "Guide book of analysis methods of milk and milk products," Ataturk University, Agricultural Faculty. Erzurum, Turkey. 2006. pp. 254.

[16] V. Scancalapore and C. Longone, "Rapid methods for measuring the degree of proteolysis as cheese ripening index," Milchwissens., vol. 43, no. 6, pp. 88-92, 1988.

[17] IDF, "Determination of nitrogen content. Standard 20B," International Dairy Federation, Brussels, Belgium, 1993.

[18] C. Alais, "Science du Lait," 4.th ed. SEPAIC, Paris, 1984. pp.814.

[19] S. Ozcan and H. Z. Senyuva, "Improved and simplified liquid chromatography/atmospheric pressure chemical ionization mass spectrometry method for the analysis of underivatized free amino acids in various foods," J Chrom A., vol. 1135, pp. 179-185, 2006.

[20] S. Yesilyurt, "Studies on the use of Fromase and Rennilase from Rhizomuchor miehei in White cheese," Ph.D. thesis, Ege Univ., Izmir, Turkey, 1992.

[21] H. R. Uysal, O. Kinik, and N. Akbulut, "Research on the possibilities of the use of chicken pepsine for the manufacture of White-brined cheese," J. Agric. Fac. Ege Univ., vol. 33, pp. 99-106, 1996.

[22] I. Saldamli and M. Kaytanli, "Utilisation of fromase, maxiren and Rennilase as alternative coagulating enzymes to rennet in Turkish White cheese," Milchwissens, vol. 53, no. 1, pp. 22-25, 1998.

[23] A. Yetismeyen, A. Cimer, M. Ozer, S. Odabasi, O. Deveci, "Effects of different rennets on quality of White brined cheese produced ultrafiltration technique," Food., vol. 23, no. 1, pp. 3-9, 1998.

[24] U. Eren-Vapur and T. Ozcan, "Effect of animal and microbial rennet on proteolysis during ripening of white brined cheese," presented at the $3^{\text {rd }}$ International Conference on Agriculture and Animal Science CAAS 2012, November, 24-25, Bangkok, Tailand, Agriculture and Animal Science, vol. 47, pp. 30-35, 2012a.

[25] TS 591, "Turkish white cheese standard," Ankara, 1989.

[26] N. Y. Farkye and P. F. Fox, "Objective indices of cheese ripening," Trends Food Sci. Tech., vol. 1, no. 2, pp. 37-40, 1990.

[27] P. F. Fox and P. L. H. McSweeney, "Proteolysis in cheese during ripening," Food Rev. Int., vol. 12, no. 4, pp. 457-509, 1996.

[28] M. C. Martinez-Cuesta, P. Fernandez de Palencia, T. Requena, and C. Pelaez, "Enzymatic ability of Lactobacillus casei subsp. casei IFPL731 for flavour development in cheese," Int. Dairy J., vol. 11, no. 8 , pp. 577-585, 2001

[29] U. Eren-Vapur, and T. Ozcan, "Determination of free amino acids in whole-fat Turkish White Brined cheese produced by animal and microbial milk-clotting enzymes with and without the addition of starter culture," Mljekarstvo., vol. 62, no. 4, pp. 241-250, 2012 b.

[30] B. H. Lee, L. C. Laleye, R. E. Simard, R. A. Holley, D.B. Emmons, and R. N. Giroux, "Influence of homofermentative lactobacilli on physicochemical and sensory properties of Cheddar cheese," J. Food Sci., vol. 55, no. 2, pp. 386-390, 1990.
[31] C. N. Lane, and P. F. Fox, "Contribution of starter and adjunct lactobacilli to proteolysis in Cheddar cheese during ripening," Int. Dairy J., vol. 6, no. 7, pp. 715-728, 1996.

[32] V. Dráb, M. Vejdová, J. Sajdok, and R. Hynek, "Proteolysis and acid phosphatase activity changes in cheeses of Gouda type made with different starter cultures," Czech J. Food Sci., vol. 17, no. 6, pp. 223234, 1999.

[33] M.C. Brome and G. K. Y. Limsowtin, "Starter peptidase activity in maturing cheese," Aust J Dairy Tech., vol. 53, no. 2, pp. 79-82, 1998.

[34] M. Ucuncu, "Determination of free amino acid accumulation of white cheese produced from cow's milk and sheep's milk during ripening period," J. Agric. Fac. Ege Univ., vol. 2, pp. 1-36, 1981.

[35] S. Kaymaz, "Research on determination of some free amino acids (Arginine, Isoleucine, Leucine, Methionine, Phenylalanine, Tyriptophane) during maturation periods of white pickled cheese made with cow's milk using starter or non starter," J. Agric. Fac. Ankara Univ., vol. 27, no. (3-4), pp. 545-560, 1982.

[36] A. A. Hayaloglu, M. Guven, P. F. Fox, J. A. Hannon, and P. L. H McSweeney. "Proteolysis in Turkish White brined cheese made with defined strains of Lactococcus," Int. Dairy J., vol. 14, no. 7, pp. 599610, 2004.

[37] E. Alichanidis, E. M. Anifantakis, A. Polychroniadou, and M. Nanou, "Suitability of some microbial coagulants for Feta cheese manufacture," J. Dairy Res., vol. 51, no. 1, pp. 141-147, 1984.

[38] M. C. Katsiari, E. Alichanidis, L. P. Voutsinas, and I. G. Roussis, "Proteolysis in reduced sodium Feta cheese made by partial substitution of $\mathrm{NaCl}$ by $\mathrm{KCl}$," Int. Dairy J., vol. 10, no. 9, pp. 635646,2000

[39] A. Michaelidou, M. C. Katsiari, E. Kondly, L. P. Voutsinas, and E. Alichanidis, "Effect of a commercial adjunct culture on proteolysis in low-fat Feta-type cheese," Int. Dairy J., vol. 13, no. 2, pp. 179-189, 2003.

[40] S. Azarnia, M. R. Ehsani, and S. A. Mirhadi, "Evaluation of the physico-chemical characteristics of the curd during the ripening of Iranian brine cheese," Int Dairy J., vol. 7, no. 6-7, pp. 473-478, 1997.

[41] L. Lemieux, and R.E. Simard, "Bitter flavour in dairy products. I. A review of the factors likely to influence its development, mainly in cheese manufacture," Lait., vol. 71, no. 6, pp. 599-636, 1991.

[42] L. Lemieux, and R.E. Simard, "Bitter flavour in dairy products. II. A review of bitter peptides from caseins: their formation, isolation and identification, structure masking and inhibition," Lait., vol. 72, no. 4 pp. 335-385, 1992.

[43] I. Kabelová, M. Dvořáková, H. Č́žžková, P. Dostálek, and K Melzoch, "Determination of free amino acids in cheeses from the Czech market," Czech J. Food Sci., vol. 27, no. 3, pp. 143-150, 2009.

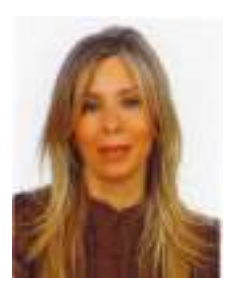

Tulay Ozcan is an associate professor of Department of Food Engineering at the Uludag University, Bursa, Turkey. More recently, she has worked in the area of rheology and texture of dairy products. From 2005 to 2006 and 2010 (21 months) she worked at University of Wisconsin-Madison USA, Department of Food Science as a visiting scientist. Topics of interest includes dairy chemistry and biochemistry, rheological properties and microstructure of yogurt, texture of yogurt and cheese, the use of dairy and plant based proteins for the production of functional dairy products, traditional cheeses and enzyme accelerated ripening of cheese, the use of fat replacer in ice cream and principles of nutrition. 